\title{
Palliative care need in patients with advanced heart failure hospitalized in a tertiary hospital
}

\author{
Necessidade de cuidados paliativos em pacientes com insuficiência \\ cardíaca avançada internados em um hospital terciário \\ Necesidad de cuidados paliativos en pacientes con insuficiencia \\ cardiaca avanzada en estancia en un hospital terciario
}

Roman Orzechowski ${ }^{1}$, André Luiz Galvão², Thaise da Silva Nunes ${ }^{1}$, Luciana Silveira Campos ${ }^{1,3}$

How to cite this article:

Orzechowski R, Galvão AL, Nunes TS, Campos LS. Palliative care need in patients with advanced heart failure hospitalized in a tertiary hospital. Rev Esc Enferm USP. 2019;53:e03413. DOI: http://dx.doi.org/10.1590/S1980-220X2018015403413

${ }^{1}$ Hospital Nossa Senhora da Conceição, Serviço de Dor e Cuidados Paliativos, Porto Alegre, RS, Brazil.

2 Hospital Nossa Senhora da Conceição, Serviço de Cardiologia, Porto Alegre, RS, Brazil.

3 Universidade do Porto, Faculdade de Medicina, Instituto de Saúde Pública, Porto, Portugal.

\begin{abstract}
Objective: To evaluate the need for palliative care in patients with advanced Congestive Heart Failure (CHF) hospitalized in a cardiology ward. Method: Application of the World Health Organization Palliative Needs tool (NECPAL) with the assistant physician, patient and/or caregiver for evaluation of indication of Palliative Care (PC). Results: 82 patients with a diagnosis of class III/IV Heart Failure or ejection fraction less than or equal to $40 \%$ in echocardiography of the last 12 months were included: Mean age $68 \pm 20$ years, 51 male patients and 31 female patients. Forty-three patients $(52.4 \%)$ were married or in consensual union and ten (12\%) lived alone. The death of 46 patients $(56.1 \%)$ in the subsequent 12 months would not surprise their physician, and forty-five patients (55\%) had palliative care indication according to the NECPAL. Conclusion: About half of patients hospitalized for class III/IV Heart Failure would have an indication of Palliative Care for the relief of suffering caused by the disease.
\end{abstract}

\section{DESCRIPTORS}

Heart Failure; Palliative Care; Prognosis; Patient Care. 


\section{INTRODUCTION}

While the number of deaths from heart disease has not changed substantially since 1990 in developed countries, there has been a $66 \%$ increase in deaths in low- or middle-income countries ${ }^{(1)}$. Because of disease characteristics, patients frequently require Palliative Care (PC) in order to relieve suffering and improve the quality of life $\mathrm{e}^{(2-3)}$.

Among chronic diseases, Congestive Heart Failure $(\mathrm{CHF})$ has the highest rate of rehospitalization and mortality ${ }^{(4)}$, which limits the life expectancy ${ }^{(5)}$. Patients with advanced $\mathrm{CHF}$ often suffer from various physical and psychosocial symptoms ${ }^{(5)}$. From the clinical point of view, $\mathrm{CHF}$ is more of a gradual decline of cardiac function with episodes of acute deterioration and discrete recovery ${ }^{(3,5-6)}$ than an episode of sudden death ${ }^{(5)}$. It affects $2-5 \%$ of adults aged between 65-75 years and >10\% of those aged 80 years and over $^{(5)}$. It is not uncommon that the patient receives aggressive treatment despite the poor prognosis ${ }^{(3)}$.

The PC model involves taking a series of measures well before the final stages of illness in the near death period. Ideally, it should be implemented together with curative treatments in cases of poor prognosis in a comprehensive patient-centered approach, and by taking into account the existential, psychosocial and clinical needs ${ }^{(3)}$.

The first step of offering PC to the population is the identification of individuals who would need of this type of care $^{(2)}$. Traditionally, $\mathrm{PC}$ needs were estimated from causes of mortality ${ }^{(7)}$, and more recently by using alternative methods of calculating prevalence or direct measures in the general population ${ }^{(8-9)}$. Among these measures, there are tools that estimate the probability of death in a given period (usually one year). An instrument capable of identifying patients who will require $\mathrm{PC}$ and predicts mortality would facilitate endof-life planning, improve quality of life, and assist managers in allocating resources efficiently ${ }^{(8)}$.

The Palliative Needs - NECPAL is a tool developed at the Collaborating Center of the World Health Organization of the Catalan Institute of Oncology to predict the mortality of chronic patients and thus, allow the planning of the care in the last year of life ${ }^{(10)}$. It has been applied in different clinical contexts ${ }^{(2,11)}$.

In a cohort designed for evaluating the mortality prediction of this tool at 12 months of follow-up, the NECPAL presented high sensitivity $(91.3 \%$ 95\% CI: 87.2-94.2\%) and high negative predictive value (91.0\% 95\% CI: 86.9-94.0).

The objective of the present study is to determine the number of adult patients with advanced Congestive Heart Failure with Palliative Care needs by using the NECPAL tool in a cardiology ward of a tertiary hospital and to quantify the perception and indication of Palliative Care by the physician.

\section{METHOD}

\section{TYPE OF STUDY}

Transversal.

\section{Population AND SAMPLE}

Consecutive sampling for convenience. The sample included patients older than 35 years of age, who were hospitalized in the Cardiology Service of a tertiary hospital between June and November 2017 with a diagnosis of Class III/IV Heart Failure or ejection fraction less than or equal to $40 \%$ on the echocardiogram of the last 12 months. Data were collected during routine care.

\section{EXCLUSION CRITERIA}

Patients who did not have cognitive conditions to respond adequately to questions of the NECPAL tool ${ }^{(2)}$, and did not have a caregiver/family member/responsible person capable of responding on their behalf.

\section{INSTRUMENTS AND DATA COLLECTION}

NECPAL (Chart 1) is an instrument that identifies clinical parameters such as functional and nutritional decline, the presence of comorbidities and syndromes, and geriatric conditions, including: care demand needs; general clinical indicators of severity and progression; clinical indicators of severity and progression of chronic pathology (oncological, pulmonary, cardiology or neurology $)^{(10)}$.

The surprise question $(\mathrm{SQ})^{(12-13)}$ is the first parameter of the NECPAL tool ${ }^{(2)}$. It is a single question asked to the patient's physician about the patient's life expectancy estimate: "Would you be surprised if this patient dies within the next 12 months?" Patients whom the doctor answered "no" are considered SQ positive ${ }^{(2,12)}$. In addition to the surprise question, the assistant physician was asked if he/she understood that the patient would have indication of Palliative Care. Both the SQ and objective indication of palliative care are items of the NECPAL tool. In order to be considered NECPAL positive, patients must present at least one additional criterion beyond the surprise question (general clinical indicators of severity and progression, including comorbidities, use of health resources, use of specific disease indicators) ${ }^{(2)}$.

The evaluation of the functionality was also estimated by researchers in the interview with the patient or responsible person through application of the Palliative Performance Scale (PPS $)^{(14)}$. The Barthel Index was used to assess patients' dependence for performing their basic activities of daily living, such as eating, bathing, hygiene, dressing, continence, mobility, among others ${ }^{(15)}$.

\section{Statistical ANALYSIS AND DATA PROCESSING}

Statistical analysis was performed through the Statistical Package for the Social Sciences (SPSS 16.0 for Windows). Continuous variables were described as mean and standard deviation and analyzed by the Student's t-test. Non-normal distribution variables were described as medians and interquartile ranges and analyzed by the Mann-Whitney test. Categorical variables were analyzed using the chi-square test.

This study corresponds to the analysis of initial data of a cohort for evaluation of the survival of these patients. 


\section{ETHICAL ASPECTS}

The Research Project was approved by the Research Ethics Committee of the Grupo Hospitalar Conceição under number
2.348.901 of 2017, thus meeting the ethical criteria in research with human beings according to Resolution 466/12 of the Ministry of Health, and use of the Informed Consent form.

Chart 1 - Palliative Needs tool (NECPAL) $)^{(2)}$

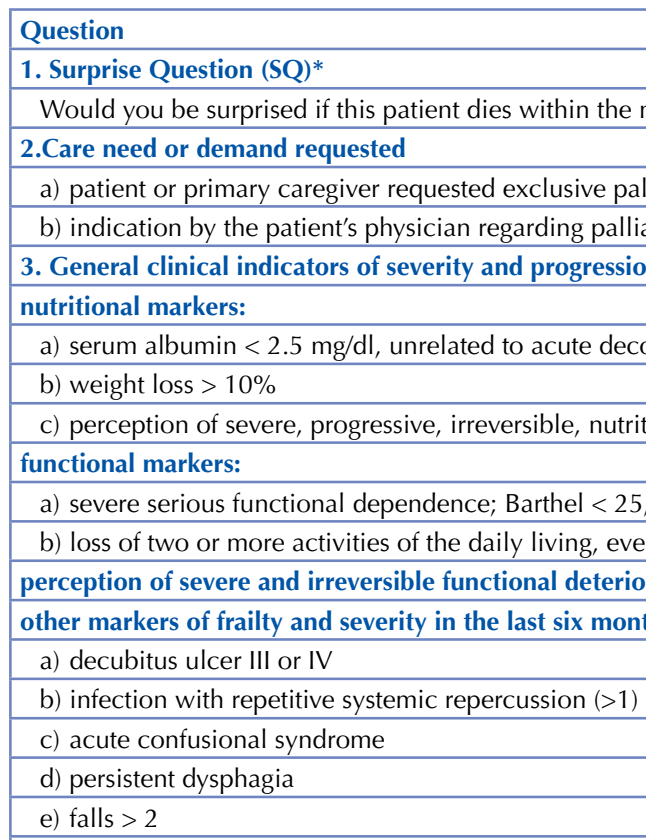

presence of emotional stress with progressive and irreversible symptoms.

additional factors on use of health services:

a) two or more admittances in emergency or elective services due to chronic illness

b) need for full/intense care at home or institution

Comorbidities $>$ two pathologies

4. Clinical indicators of severity and progressive pathology

neoplasm (one single criterion)

a) diagnosis of metastatic cancer, contraindication of specific treatment, affects vital organs such as lung, liver, central nervous system

b) significant functional impairment PPS $<50 \%$

c) poorly controlled persistent symptoms despite optimal treatment

chronic obstructive pulmonary disease (two or more criteria):

a) dyspnea at rest or at minimal exertion between exacerbations

b) physical and psychological symptoms of difficult handling

c) severe obstruction criteria FEv $1<30 \%$ CVF $<40 \%$

d) indication of home oxygen therapy by gasometry criteria

e) associated heart failure

f) hospitalizations $>3$ in 12 months by COPD

chronic heart disease (two or more criteria):

a) Class III or IV CHF, valvar insufficiency and chronic coronary disease

b) dyspnea or angina at rest

c) physical and psychological symptoms of difficult treatment

d) in case of echography: ejection fraction $<30 \%$ or severe pulmonary hypertension $>60 \mathrm{mmHg}$

e) renal failure: glomerular filtration rate $<30 \mathrm{~L} / \mathrm{min}$

f) hospital or emergency admission $>$ three in the last year

chronic neurological disease (arterial or venous, a single criterion)

a) subacute phase $<$ three months; vegetative state $>$ three days

b) chronic phase $>$ three months; recurrent pneumonia, pyelonephritis $>1$, persistent fever $>1$ week, grade III or IV pressure ulcer

chronic neurological disease: amyotrophic lateral sclerosis and motor neuron diseases, Parkinson's disease, multiple sclerosis (two or more criteria)
a) physical deterioration
b) complex and difficult to control symptoms
c) difficulty with communicating
d) progressive dysphagia
e) recurrent pneumonia

\begin{tabular}{|l|}
\hline Yes or No \\
\hline \\
\hline \\
\hline \\
\hline \\
\hline
\end{tabular}


...continuation

\begin{tabular}{|l|l|}
\hline Question & Yes or No \\
\hline chronic liver disease (a single criterion) & \\
\hline $\begin{array}{l}\text { a) advanced cirrhosis: CHILD C, MELD-Na > 30 HDA with one of the following complications: diuretic resistant ascites, hepatorenal } \\
\text { syndrome or portal hypertension with persistent digestive bleeding without response to drug or endoscopic treatment }\end{array}$ & \\
\hline b) stage C or D hepatocellular carcinoma & \\
\hline chronic renal failure: glomerular filtration rate < $\mathbf{1 5}$ with no indication of substitute treatment or transplantation \\
\hline dementia (two or more criteria) & $\begin{array}{l}\text { a) criteria of severity: inability to dress, shower and feed without assistance, urinary and fecal incontinence or inability to } \\
\text { communicate meaningfully }\end{array}$ \\
\hline b) loss of more than two daily activities in the last months, difficulty swallowing, denial to eat \\
\hline c) > three readmissions or emergency service requests in the last 12 months \\
\hline
\end{tabular}

* Consider as positive NECPAL the patients for whom the SQ response is "no", and at least another question with a "yes" answer to items 3, 4,5.

Source: Adapted from Batiste XG, Martínez-Muñoz M, Blay C, Amblàs J, Vila L, Costa X, et al ${ }^{(2)}$

\section{RESULTS}

Table 1 shows the general characteristics of patients included in the sample. Table 2 shows palliative care indications for this population by different criteria. The death of 46 patients (56.1\%) in the next 12 months would not be surprising to their physicians. Forty-five patients (55\%) had indication of palliative care according to the NECPAL tool $^{(2)}$. Thirty patients or their family members $(36 \%)$ requested the introduction of exclusive palliative care, measures of comfort or restriction of therapeutic effort. When questioned, physicians would indicate palliative care for 47 (57.3\%) patients.

Table 3 shows the relationships between positivity for the NECPAL tool ${ }^{(2)}$ and additional criteria in this population. The most frequently associated criteria with positivity of the NECPAL tool ${ }^{(2)}$ were indicators of malnutrition, loss of functionality, frailty and presence of comorbidities.

Table 1 - Characterization of sample of 82 patients with advanced CHF - Porto Alegre, Brazil, 2017.

\begin{tabular}{lc}
\hline Variable & Results \\
\hline Age & $68 \pm 20$ \\
Sex (M/F) & $51 / 31$ \\
Married & $43(52.4 \%)$ \\
Living alone & $10(12 \%)$ \\
Schooling* & 5 years \\
PPS* & 80 \\
Barthel* & 95 \\
\hline
\end{tabular}

*Median.

Table 2 - Indication of Palliative Care (PC) in a population of patients with advanced CHF - Porto Alegre, Brazil, 2017.

\begin{tabular}{lc}
\hline Questions & $\mathrm{N}(\%)$ \\
\hline Surprise question + & $46(56.1 \%)$ \\
NECPAL $+^{2}$ & $45(55 \%)$ \\
PC request by family member & $30(36.6 \%)$ \\
PC indication by physician & $47(57.3)$ \\
\hline Total & $\mathbf{8 2 ( 1 0 0 \% )}$ \\
\hline
\end{tabular}

Table 3 - Relationship between additional criteria and positivity of the NECPAL tool ${ }^{(2)}$ - Porto Alegre, Brazil, 2017.

\begin{tabular}{lcc}
\hline NECPAL too $^{2}$ & $\mathbf{N}(\%)$ & $\mathbf{P}^{*}$ \\
\hline nutritional & $20(25)$ & $<0.001$ \\
functionality & $15(18.3)$ & $<0.001$ \\
frailty & $15(18)$ & $<0.001$ \\
stress & $19(23)$ & 0.008 \\
comorbidities & $54(65.9)$ & $<0.001$ \\
neoplasm & $3(3.7)$ & 0.313 \\
neurovascular & $2(2.4)$ & 0.563 \\
neuro-chronic & $1(1.2)$ & 1.00 \\
hepatic & $1(1.2)$ & 1.00 \\
dementia & $1(1.2)$ & 1.00 \\
COPD & $19(23.2)$ & 0.008 \\
\hline Total & $\mathbf{8 2}(\mathbf{1 0 0} \%)$ & \\
\hline
\end{tabular}

*chi-square test

\section{DISCUSSION}

The physician's specialty, experience and the nature of the physician-patient relationship may influence the accuracy of survival prediction ${ }^{(16)}$. An instrument that can identify patients who will require PC and predict mortality would facilitate end-of-life planning, improve patients' quality of life, and assist managers in allocating resources efficiently ${ }^{(8)}$. The Palliative Care model involves taking some measures well before the final stages of illness in the period close to death ${ }^{(3)}$.

The surprise question is the first parameter of the NECPAL tool ${ }^{(2)}$. In a study with 231 patients, the + SQ response predicted $83.8 \%$ of deaths ${ }^{(12)}$. In our study, physicians would not be surprised if 46 (56.1\%) of patients died in the 12 months following that hospitalization therefore, they would have indicated an institution of Palliative Care.

The number of patients that would have indication of PC if the NECPAL criteria were applied was slightly lower: 45 (55\%). A Spanish cohort was designed to estimate the PC needs and mortality of 1,064 patients with chronic diseases by the SQ and NECPAL. All NECPAL + patients were considered as needing PC. At 12 months of followup, NECPAL presented high sensitivity $(91.3 \%$ 95\%CI: 
87.2-94.2) and high negative predictive value (91.0\% 95\%CI: 86.9-94.0) with low specificity (32.9\% 95\%CI: 29.6$36.3)$, which were explained by the large number of false positives and a low positive predictive value $(33.5 \% 95 \% \mathrm{CI}$ : 30.2-36.9). The authors mentioned the need for new studies investigating other factors of poor prognosis (frailty, geriatric syndromes, cognitive deficit, malnutrition and multi morbidity) and the investigation of specific diseases to increase the predictive value of NECPAL ${ }^{(8)}$.

With demographic changes and population aging, chronic diseases are becoming the leading cause of palliative care need ${ }^{(3,17)}$. Our data demonstrated that about $55 \%$ of patients hospitalized for class III and IV CHF in a tertiary hospital would have an indication for $\mathrm{PC}$, and demographic changes and multiple comorbidities require new incentives for the improvement and expansion of this type of care network $^{(18)}$. In Brazil, PC has been targeted to patients with advanced neoplasia, and patients with other end-of-life diseases have not been satisfactorily addressed ${ }^{(19)}$. In a recently published study in which was evaluated the Brazilian mortality on year 2014, were made projections of PC needs for patients whose cause of death were chronic diseases. In the more conservative projection, it was estimated that 301.95 patients $(25 \%)$ would have benefited from palliative care. The authors suggested training the existing human resources for performing palliative actions, since extension of the secondary and tertiary care network in a short period of time would be impracticable ${ }^{(20)}$.

\section{CONCLUSION}

The data from our study indicated that about half of patients hospitalized for class III/IV CHF in a tertiary hospital would have an indication of Palliative Care for the relief of suffering caused by the disease and improvement of the quality of life. New studies are needed for long term follow-up in order to evaluate the NECPAL tool in different health contexts of the Brazilian population.

\section{RESUMO}

Objetivo: Avaliar a necessidade de Cuidados Paliativos em pacientes com Insuficiência Cardíaca Congestiva Avançada internados em uma enfermaria cardiológica. Método: Estudo transversal com a aplicação da Escala Necessidades Paliativas da Organização Mundial da Saúde ao médico-assistente e ao paciente e/ou responsável, para avaliar a indicação de Cuidados Paliativos em pacientes com diagnóstico de Insuficiência Cardíaca classes III/IV ou fração de ejeção menor ou igual a $40 \%$ em ecocardiografia dos últimos 12 meses. Resultados: Foram incluídos 82 pacientes. A média de idade de $68 \pm 20$. Cinquenta e um pacientes do sexo masculino e 31 do sexo feminino. Quarenta e três pacientes $(52,4 \%)$ eram casados ou estavam em união consensual, e 10 (12\%) moravam sozinhos. O óbito de 46 pacientes $(56,1 \%)$ nos 12 meses subsequentes não surpreenderia o seu médico, e 45 pacientes (55\%) tiveram indicação de cuidados paliativos. Conclusão: Cerca da metade dos pacientes que foram internados por Insuficiência Cardíaca classe III-IV teria indicação de Cuidados Paliativos para o alívio do sofrimento provocado pela doença.

\section{DESCRITORES}

Insuficiência Cardíaca; Cuidados Paliativos; Prognóstico; Assistência ao Paciente.

\section{RESUMEN}

Objetivo: Evaluar la necesidad de Cuidados Paliativos en pacientes con Insuficiencia Cardiaca Avanzada en estancia en una enfermería cardiológica. Método: Estudio transversal con la aplicación de la Escala Necesidades Paliativas de la Organización Mundial de la Salud al médico asistente y al paciente y/o responsable, a fin de evaluar la indicación de Cuidados Paliativos en pacientes con diagnóstico de Insuficiencia Cardiaca clases III/IV o fracción de eyección menor o igual que el $40 \%$ en ecocardiografía de los últimos 12 meses. Resultados: Fueron incluidos 82 pacientes, con promedio de edad de $68 \pm 20$; cincuenta e un pacientes del sexo masculino y 31 del sexo femenino. Cuarenta y tres pacientes $(52,4 \%)$ estaban casados o en pareja de hecho y 10 (12\%) vivían solos. El fallecimiento de 46 pacientes $(56,1 \%)$ en los 12 meses subsiguientes no sorprendería a su médico, y 45 pacientes $(55 \%)$ tuvieron indicación de cuidados paliativos. Conclusión: Cerca de la mitad de los pacientes que fueron hospitalizados por Insuficiencia Cardiaca clase III-IV tendrían indicación de Cuidados Paliativos para el alivio del sufrimiento provocado por la enfermedad.

\section{DESCRIPTORES}

Insuficiencia Cardíaca; Cuidados Paliativos; Pronóstico; Atención al Paciente.

\section{REFERENCES}

1. Espinosa J, Martınez-Muñoz M, Lasmarıas C, Beas E, Mateo-Ortega D, Novellas A, et al. The WHO Collaborating Centre for Public Health Palliative Care Programs. An innovative approach of palliative care development. J Palliat Med. 2014;17(4):385-92. DOI: https://doi. org/10.1089/jpm.2013.0203

2. Batiste XG, Martínez-Muñoz M, Blay C, Amblàs J, Vila L, Costa X, et al. Utility of the NECPAL tool and the Surprise Question for early palliative care to predict mortality with chronic conditions: a cohort study. Palliat Med. 2017;31(8):754-63. DOI: https://doi. org/10.1177/0269216316676647

3. Martín-Lesende I, Recalde E, Viviane-Wunderling P, Pinar T, Borghesi F, Aguirre T, et al. Mortality in a cohort of complex patients with chronic illnesses and multimorbidity: a descriptive longitudinal study. BMC Palliat Care. 2016;15:42. DOI: https://doi.org/10.1186/ s12904-016-0111-x

4. Bocchi EA, Marcondes-Braga FG, Bacal F, Ferraz AS, Albuquerque D, Rodrigues D, et al.; Sociedade Brasileira de Cardiologia. Atualização da diretriz brasileira de insuficiência cardíaca crônica - 2012. Arq Bras Cardiol. 2012;98(1 Supl.1):1-33. DOI: http://dx.doi.org/10.1590/ S0066-782X2012001000001

5. Klindworth K, Oster P, Hager K, Klause O, Bleidorn J, Schneider N. Living with and dying from advanced heart failure: understanding the needs of older patients at the end of life. BMC Geriatr. 2015;15:125. DOI: https://doi.org/10.1186/s12877-015-0124-y 
6. McClung JA. End-of-life care in the treatment of heart failure in older adults. Heart Fail Clin. 2017;13(3):633-44. DOI: https://doi. org/10.1016/j.hfc.2017.02.014

7. Burlá C, Goreti M. Prognóstico: doença cardíaca. In: Carvalho R, Parsons H, organizadores. Manual de cuidados paliativos. $2^{a}$ ed. Rio de Janeiro: Diagraphic; 2012. p. 58-62.

8. Gómez-Batiste X, Martínez-Muñoz M, Blay C, Amblàs J, Vila L, Costa X, et al. Utility of the NECPAL CCOMS-ICO ${ }^{\circ}$ tool and the surprise question as screening tools for early palliative care and to predict mortality in patients with advanced chronic conditions: a cohort study. Palliat Med. 2017;31(8):754-63. DOI: https://doi.org/10.1177/0269216316676647

9. Murtagh FE, Bausewein C, Verne J, Groeneveld EI, Kaloki YE, Higginson IJ. How many people need palliative care? A study developing and comparing methods for population-based estimates. Palliat Med. 2014;28(1):49-58. DOI: https://doi.org/10.1177/0269216313489367

10. Gómez-Batiste X, Pascual A, Espinosa J, Caja C. Diseño, implementación y evaluación de programas públicos de cuidados paliativos. Med Clin (Barc). 2010;135(4):179-85. DOI: 10.1016/j.medcli.2010.02.007

11. Gómez-Batiste X, Martínez-Muñoz M, Blay C, Amblàs J, Vila L, Costa X, et al. Prevalence and characteristics of patients with advanced chronic conditions in need of palliative care in the general population: a cross-sectional study. Palliat Med. 2014;28(4):302-11. DOI: $10.1177 / 0269216313518266$

12. Moroni M, Zocchi D, Bolognesi D, Abernethy A, Rondelli R, Savorani G, et al. The 'surprise' question in advanced cancer patients: a prospective study among general practitioners. Palliat Med. 2014;28(7):959-64. DOI: https://doi.org/10.1177/0269216314526273

13. Sousa PF, Julião M. Translation and validation of the Portuguese version of the Surprise Question. J Palliat Med. 2017;20(7):701-702. DOI: 10.1089/jpm.2017.0086

14. Victoria Hospice Society. Palliative Performance Scale (PPSv2) [Internet]. Victoria, BC: Medical Care of the Dying; 2006 [cited 2018 Mar 16]. Available from: http://www.victoriahospice.org/sites/default/files/imce/PPS\%20ENGLISH.pdf

15. Minosso JSM, Amendola F, Alvarenga MRM, Oliveira MAC. Validação no Brasil do Índice Barthel em idosos atendidos em ambulatório. Acta Paul Enferm [Internet]. 2010 [citado 2018 mar. 16];23(2):218-23. Disponível em: http://www2.unifesp.br/acta/pdf/v23/n2/v23n2a11. pdf

16. Glare P, Virik K, Jones M, Hudson M, Eychmuller S, Simes J, et al. A systematic review of physicians' survival predictions in terminally ill cancer patients. BMJ. 2003;327(7408):195-8. DOI: 10.1136/bmj.327.7408.195

17. Dang S, Karanam C, Gómez-Marín O. Outcomes of a mobile phone intervention for heart failure in a minority county hospital population. Telemed J Health. 2017;23(6):473-84. DOI: https://doi.org/10.1089/tmj.2016.0211

18. Murray SA, Kendall M, Boyd K, Sheikh A. Illness trajectories and palliative care. BMJ. 2005;330(7498):1007-11. DOI: https://doi. org/10.1136/bmj.330.7498.1007

19. Floriani CA. Palliative care in Brazil: a challenge to the healthcare system. Palliat Care Res Treat [Internet]. 2008 [cited 2018 Mar 16];2:1924. Available from: http://journals.sagepub.com/doi/full/10.1177/117822420800200001

20. Santos CE, Caldas JMP, Serafim JA, Barros N, Pereira AC, Capra MEZ, et al. Palliative care in Brazil: with a view to future needs? Int Arch Med. 2017;10:1-9. DOI: https://doi.org/10.3823/2418 